\title{
Uwagi o ksiazżce Piotra Zbigniewa Pomianowskiego Początki polskiego czasopiśmiennictwa prawniczego. Seria pierwsza "Themis Polskiej", Warszawa 2015, 279 ss.
}

\begin{abstract}
Remarks on Piotr Zbigniew Pomianowski's The Beginnings of Polish Legal Literature. The First Seria of "Themis Polska", Warsaw 2015, 279 pp.

The article is a review of a book which is dedicated to Themis Polska - a Polish periodical that appeared in the years 1829-1830. The book being reviewed is the published version of a doctoral thesis defended at the Faculty of Law and Administration of the University of Warsaw in 2012. The author of the review conducted a meticulous and critical discussion of chapters of the book. In the summary he concluded that the work is a discussion of the content of the journal and a compilation of the views of its authors. In addition, the reviewer poses a rhetorical question about the scientific usefulness of this kind of works, in particular as regards their financing from public funds.
\end{abstract}

Keywords: Polish legal periodical, Themis Polska Journal, Polish law in the 19th century, taxpayer's interest

Słowa kluczowe: polskie czasopiśmiennictwo naukowe, czasopismo Themis Polska, prawo polskie XIX w., interes podatnika

1. W 2011 roku na łamach „Forum Prawniczego” ukazał się artykuł recenzyjny, w którego zakończeniu stwierdziłem explicite, że „W ten sposób można wyobrazić sobie prace naukowe dotyczące wyłącznie historii poszczególnych czasopism prawniczych, ich zawartości, w tym poszczególnych gałęzi prawa czy instytucji prawnych"1. Warto jednak zaznaczyć, że poprzednio recenzowana praca dotyczyła nauki prawa karnego w środowisku „Gazety Sądowej Warszawskiej” w latach 1873-1918, czyli ponad 40 lat. Recenzowana książka obejmuje natomiast okres zaledwie trzech lat.

1 R. Jastrzębski, Recenzja książki Marzenny Paszkowskiej Nauka prawa karnego w środowisku „Gazety Sądowej Warszawskiej” (1873-1918), „Forum Prawnicze” 2011, nr 6, s. 81. 
Poczatki polskiego czasopiśmiennictwa prawniczego. Seria pierwsza „Themis Polskiej" zostały wydane nakładem Wydawnictwa Campidoglio, a nazwa wydawnictwa, jak należy przypuszczać, nawiązuje do określenia Kapitolu - wzgórza w Rzymie na północny zachód od Palatynu i Forum Romanum. Wydawnictwo mieści się w Podkowie Leśnej, przy ulicy Borsuczej, i działa na rynku wydawniczym od maja 2007 roku$^{2}$. Jak wynika z tytułów wydanych książek, wydawnictwo specjalizuje się między innymi w publikowaniu książek o tematyce prawno-historycznej³ .

2. Recenzowana książka stanowi poprawioną wersję pracy doktorskiej, a jej autor zarówno w nocie „Od autora”, jak i na stronie poprzedzającej spis treści zadedykował ją Annie Rosner - jak należy domniemywać, swojej mentorce. W nocie bowiem Piotr Zbigniew Pomianowski zaznaczył, że A. Rosner kierowała jego edukacją jako tutor w Kolegium Międzywydziałowych Indywidualnych Studiów Humanistycznych oraz zwróciła mu uwagę na problematykę, którą zajął się podczas studiów doktoranckich.

Książka składa się z 10 rozdziałów, zakończenia oraz bibliografii. Pierwszy rozdział ma charakter wprowadzający, w praktyce zaś jest to wstęp do książki. Autor poruszył w nim między innymi stan badań, zakres przedmiotowy pracy, pokrótce opisał system prawny Królestwa Polskiego, kulturę prawną doby królestwa, europejskie czasopiśmiennictwo prawnicze w pierwszej połowie XIX wieku oraz początki polskiego czasopiśmiennictwa prawniczego. Już prima facie wymienione zagadnienia, stanowiące podrozdziały, nie są z sobą spójne, dotyczą bowiem bardzo różnych kwestii. Ponadto brak omówienia pojęcia kultury prawnej ${ }^{4}$ czy akulturacji. Dlatego należałoby niejako wyjąć poza nawias z treści rozdziału odrębny wstęp, a także omówić, jako osobny rozdział, europejskie czasopiśmiennictwo prawnicze z pierwszej połowy XIX wieku. Ostatnie zagadnienie wymagałoby od autora większego nakładu pracy w porównaniu z przedstawionym zarysem, gdyż omówił on jedynie czasopisma prawnicze we Francji, krajach niemieckich, Anglii oraz Niderlandach.

Kolejny rozdział, notabene o objętości zaledwie niecałych 9 stron, dotyczy genezy czasopisma „Themis Polska”, w tym jego założenia oraz programu. W zakończeniu rozdziału autor uznał, że ,postulowano w nim [tj. czasopiśmie] określone zmiany [tj. w systemie prawnym], ale oczekiwane nowelizacje mieściły się w ramach nowego paradygmatu, nowych punktów odniesienia wyznaczonych przez Rewolucję

2 Zgodnie z danymi, które znajdują się na stronie internetowej wydawnictwa.

3 Zob. A.B. Zakrzewski, Wielkie Księstwo Litewskie (XVI-XVIII w.). Prawo-ustrój-społeczeństwo, Warszawa 2013; A. Moniuszko, Mazowieckie sady ziemskie (1588-1648). Organizacja - funkcjonowanie - postępowanie, Warszawa 2013; Ł. Gołaszewski, Spory o dziesięciny. Świeccy i duchowni w Knyszynie na przetomie XVI i XVII wieku, Warszawa 2016; A. Moniuszko, Prawo sadowe Rzeczypospolitej szlacheckiej (XVI-XVII w.). Zarys wyktadu z wyborem źródet, Warszawa 2017; P.Z. Pomianowski, Rozwód w XIX wieku na centralnych ziemiach polskich. Praktyka stosowania Kodeksu Napoleona w latach 1808-1852, Warszawa 2018.

4 Zob. K. Pałecki, O użyteczności pojęcia kultura prawna, „Państwo i Prawo” 1974, z. 2; K. Sójka-Zielińska, Stanisława Russockiego dyskurs historyczny o kulturze prawnej [w:] Stanisław Russocki - badacz dziejów ustroju i prawa. W 45-lecie pracy naukowej, Warszawa 1999; S. Grodziski, Z dziejów staropolskiej kultury prawnej, Kraków 2004. 
Francuską", a „W dobie wstecznych zmian, które zachodziły w Królestwie Polskim w trzeciej dekadzie XIX w., ugruntowanie przekonania, że powrotu do starego już nie ma, było zatem jednym z zasadniczych celów pisma" (s. 55 recenzowanej książki). Cytowany in extenso fragment książki, jak należy domniemywać, dotyczy nowego spojrzenia na prawo w XIX wieku, w związku z powstaniem czasopisma.

W trzecim rozdziale autor zajął się osobami związanymi z czasopismem, to znaczy pomysłodawcami, jego organizatorami, składem redakcji gazety, autorami opublikowanych prac, dystrybutorami oraz prenumeratorami. Związane są z tym rozważania autora na temat stopki redakcyjnej (s. 60-61 książki); w szczególności mogą budzić co najmniej zdziwienie refleksje o decyzji jej publikowania na przełomie 1829 i 1830 roku. Podobnie rzecz ma się z wnioskami autora, że redakcja czasopisma miała charakter kolegialny, w tym „kolegialne kierowanie pismem nie było w ówczesnych realiach polskiej prasy rzadkością” (s. 67 książki). Ponadto uznał on, iż „,dane biograficzne, jak i opublikowane na łamach «Themis Polskiej» prace pozwalają stwierdzić, że wszyscy oni mieli podobny typ umysłowości. Wyróżniali się nowoczesnym podejściem do prawa, które zasadniczo utożsamiali z prawem pozytywnym, a którego przepisy interpretowali według powszechnie przyjętych metod wykładni, rzadko odwołując się do poczucia sprawiedliwości czy zwyczajów" (s. 64 książki). Autor wymienił także skład redakcji oraz zwrócił uwagę na pochodzenie jej członków, stwierdzając - bez żadnej jednak głębszej refleksji - że między innymi Jan Kanty Wołowski pochodził z rodziny frankistowskiej, być może nobilitowanej, a Karol Boromeusz Hoffman zawdzięczał swoją karierę upadkowi, czy może lepiej ograniczeniom feudalizmu (s. 65 książki). Następnie autor książki wymienił autorów artykułów opublikowanych na łamach czasopisma, przyporządkowując im określoną liczbę prac, które ukazały się w ciągu trzech lat. Zakończenie rozdziału, liczące niecałe trzy strony, zostało poświęcone dystrybutorom oraz prenumeratorom gazety, którzy zostali podzielni między innymi ze względu na wykonywany zawód. Ostatecznie autor doszedł do „odkrywczego" wniosku, że „czasopismo było przeznaczone niemal wyłącznie dla praktyków, głównie związanych z sądownictwem" (s. 74 książki).

Następny rozdział pracy dotyczy organizacji procesu wydawniczego i liczy zaledwie 11 stron. W swoich rozważaniach autor zwrócił uwagę między innymi na przedsiębiorstwo wydające ,Themis Polską", promocję czasopisma, politykę cenową (prenumeraty czasopisma), zagadnienie wynagrodzeń, uznając przy tym, że analiza ksiąg handlowych drukarni nie daje bynajmniej jednoznacznej odpowiedzi na pytanie, czy autorzy publikacji na łamach tego czasopisma otrzymywali z tego tytułu wynagrodzenie pieniężne. W związku z tym dokonał on wnikliwej egzegezy nekrologu K.B. Hoffmana, autorstwa Adolfa Pawińskiego, zaznaczając, iż „na Zachodzie przynajmniej niektórzy wydawcy czasopism prawniczych płacili autorom tekstów" (s. 78-79 książki). Ponadto zwrócił uwagę na cenę prenumeraty, zaznaczając, że cena jednego poszytu ${ }^{5}$ wynosiła w Warszawie od 2,5 do 5 zł, a za 2,5 zł można było w 1830

Poszyt - zszyta i oprawiona zazwyczaj w półsztywny karton grupa akt, która jest zwykle jednostką archiwalną lub jej częścią. W związku z tym używanie przez autora pojęcia „,poszyt” na określenie kolejnych tomów gazety jest nieuprawnione. 
roku kupić ponad 40 bochenków chleba o wadze około jednego kilograma lub ponad 11 kilogramów wołowiny. Omawiając szatę zewnętrzną gazety, zwrócił on natomiast uwagę na liczne błędy w zakresie ciągłości numeracji stron. Kolejnym ,ważkim problemem" dla autora książki była kwestia wydawania kolejnych poszytów, co znalazło się w podrozdziale o nielogicznym tytule: „Daty wejścia kolejnych poszytów”. $\mathrm{Na}$ zakończenie rozdziału autor zajął się zasięgiem oddziaływania gazety oraz sprawą cenzury. W pierwszym przypadku wręcz zaryzykował „z dużą odwagą" tezę, że „Themis Polska” była znana polskim prawnikom żyjącym nie tylko w Królestwie Kongresowym, ale także w Krakowie i na pozostałych ziemiach polskich pod zaborami. Poza tym „domniemywał”, że publicyści gazety, zwykle pracujący w aparacie administracyjnym, sami niejako dokonywali autocenzury.

Piąty rozdział książki został poświęcony, jak głosi jego tytuł, analizie zawartości czasopisma z użyciem metod ilościowych. Co istotne, stanowi w dużej mierze powtórzenie ustaleń autora zawartych w artykule z 2009 roku, który ukazał się na łamach „Studia Iuridica”, przy czym zamieszczone wykresy kolumnowe - na pierwszy rzut oka - nieznacznie różnią się od tych zawartych w książce. Odczuwalny jest natomiast brak wykresów liniowych, kołowych, słupkowych czy warstwowych. Autor dokonał także procentowego określenia poszczególnych działów - gałęzi prawa, w tym zaproponował nową klasyfikację ze względu na rzeczywistą treść poszczególnych tekstów, a nie tylko ich tytuły. Następnie zwrócił uwagę na przedruki na łamach czasopisma, które według jego wyliczeń objęły niemal $14 \%$ zawartości gazety, oraz cytowania. Ostatnie zagadnienie, co należy przyjąć „z ogromnym ubolewaniem”, objęło zaledwie 37 wybranych losowo artykułów ze wszystkich tomów czasopisma. W związku z tym autor zamieścił w książce trzy wykresy kolumnowe obrazujące liczbę cytowań w poszczególnych językach, prac z poszczególnych krajów oraz prac sklasyfikowanych ze względu na język publikacji.

Kolejny rozdział - szósty - dotyczy nurtów myśli prawniczej „,wśród publicystów «Themis Polskiej»". Autor w sposób wyjątkowo skrótowy zajął się w nim, jak to sam określił, „,wpływami” na łamach „Themis Polskiej” idei prawa natury, tak zwanej szkoły egzegezy, szkoły historycznej, szkoły filozoficznej (heglowskiej filozofii prawa). Warto odnotować, że w podsumowaniu rozdziału doszedł on do kolejnego „odkrywczego" wniosku, że „publicyści «Themis Polskiej» znajdowali się pod wpływami różnych europejskich prądów umysłowych" (s. 132 książki). Co istotne, autor książki zajmował się tym zagadnieniem w swojej wcześniejszej publikacji z 2011 roku? .

W rozdziale VII książki rozważania P.Z. Pomianowskiego ogniskują się wokół zagadnienia historii prawa na łamach „Themis Polskiej”, w tym stosunku do staropolskiej kultury prawnej. Zaznaczył przy tym, że artykuł wstępny gazety, stanowiący swoisty manifest całej redakcji, był „wyrazem odcięcia się od przedrozbiorowej kultury prawnej i wezwaniem do rozwijania nauki prawa w Polsce na podstawie

6 Zob. P. Pomianowski, Seria pierwsza ,,Themis Polskiej” jako pismo poświęcone praktyce prawa, „Studia Iuridica” 2009, t. 50.

7 Zob. P. Pomianowski, Główne nurty ideologiczno-metodologiczne w środowisku warszawskich prawników przed wybuchem powstania listopadowego, „Zeszyty Prawnicze UKSW” 2011, nr 4. 
wzorców zachodnich" (s. 136 książki). Ponadto zwrócił on uwagę na znaczenie oraz obowiązywanie prawa rzymskiego w I Rzeczypospolitej. W związku z tym postawił „retoryczne” pytanie, czy prawo rzymskie miało charakter prawa subsydiarnego na ziemiach Rzeczypospolitej.

Autor nie powołał się przy tym na żadne opracowanie z zakresu badań nad dawnym prawem polskim, w szczególności takich autorów jak Przemysław Dąbkowski, Stanisław Kutrzeba, Stanisław Płaza czy Wacław Uruszczak ${ }^{8}$. Ograniczył się natomiast tylko do polemik na łamach czasopisma, cytując obszernie ogłoszone w nim artykuły na ten temat. Poza tym opisał on status korektury pruskiej i statutu litewskiego, zadając kolejne pytania, postulaty i tezy, dotyczące między innymi obowiązywania tych regulacji w centralnych powiatach ziem polskich. Autor zwrócił także uwagę na znaczenie historii prawa, cytując obficie wypowiedzi pochodzące z poszczególnych publikacji, które ukazały się na łamach „Themis Polskiej”. Na zakończenie rozdziału doszedł on do co najmniej dyskusyjnego wniosku, że prawo rzymskie wzbudzało zainteresowanie również ze względu na to, iż Kodeks Napoleona opierał się w dużym stopniu na dorobku romanistyki (s. 150 książki). W związku z tym warto przytoczyć fragment rudymentarnego podręcznika akademickiego profesor Katarzyny SójkiZielińskiej, która stwierdziła że:

W swych założeniach ogólnych [Kodeks Napoleona] opierał się na zasadach indywidualizmu i liberalizmu. Natomiast w rozwiązaniach szczegółowych KN nawiązywał do dawnego prawa francuskiego, stanowiąc harmonijne połączenie norm zaczerpniętych z prawa zwyczajowego Francji północnej, prawa rzymskiego krajów prawa pisanego i prawa okresu Rewolucji [...]. Rewolucyjny charakter miały przede wszystkim przepisy prawa majątkowego. Natomiast w prawie osobowym KN zachował wiele elementów dawnej epoki, szczególnie w patriarchalnej koncepcji legalnej rodziny, podporządkowanej całkowicie władzy ojca i męża (zaważył tu ponoć osobisty wpływ Napoleona reprezentującego w tej mierze tradycje rodzinnej Korsyki) i wiążącym się z tym drastycznym upośledzeniem kobiet zamężnych i dzieci nieślubnych ${ }^{9}$.

Następny rozdział został poświęcony publikacjom z zakresu organizacji wymiaru sprawiedliwości, czyli postępowaniu kasacyjnemu, sporom kompetencyjnym, sądownictwu administracyjnemu. Autor wylicza w nim artykuły dotyczące wyżej wymienionych zagadnień oraz cytuje je obszernie. W przypadku ostatnich dwóch kwestii, to znaczy sporów kompetencyjnych oraz sądownictwa administracyjnego, wręcz poraża brak podstawowej literatury przedmiotu ${ }^{10}$.

8 Zob. P. Dąbkowski, Prawo prywatne polskie, t. I, Lwów 1910, t. II, Lwów 1911; S. Kutrzeba, Dawne polskie prawo sądowe $w$ zarysie, Lwów 1926; S. Płaza, Historia prawa w Polsce na tle porównawczym, cz. 1-3, Kraków 2002-2003; W. Uruszczak, Próba kodyfikacji prawa polskiego w pierwszej połowie XVI wieku. Korektura praw z 1532 r., Warszawa 1979.

9 K. Sójka-Zielińska, Historia prawa, Warszawa 1997, s. 243. Szerzej: K. Sójka-Zielińska, Wielkie kodyfikacje cywilne XIX wieku, Warszawa 1973, s. 85 i n.; K. Sójka-Zielińska, Wielkie kodyfikacje cywilne. Historia i współczesność, Warszawa 2009, s. 198 i n.

10 Zob. A. Okolski, O sporach administracyjnych. Rozprawa napisana w celu uzyskania stopnia Doktora Prawa i Administracji w Szkole Głównej Warszawskiej, Warszawa 1867; A. Mogilnicki, Sądy administracyjne (Przedruk z ,,Gazety Sądowej”), Warszawa 1900; G. Bałtruszajtys, Sądownictwo Komisji Skarbowych w sprawach handlowych i przemystowych (1764-1794), Warszawa 1977; M. Wąsowicz, Rozstrzyganie sporów prawnych między podmiotami własności publicznej w Królestwie Polskim w latach 1817-1867, CPH 1981, t. 33, z. 1; W. Witkowski, Sądownictwo administracyjne w Księstwie Warszawskim i Królestwie 
Ostatnie dwa rozdziały książki - rozdział IX i X - dotyczą odpowiednio publikacji na temat prawa karnego oraz cywilnego, które ukazały się na łamach „,Themis Polskiej”. Według obliczeń autora problematyka karnistyczna zajmuje 14\%, a publikacje $\mathrm{z}$ zakresu prawa cywilnego i procedury cywilnej w sumie 1/3 zawartości gazety (s. 175, 207 książki). Jednocześnie rozdziały zostały podzielone na instytucje, zagadnienia prawne, którym poświęcono poszczególne artykuły zamieszczone w gazecie. I tak w przypadku prawa karnego w książce wydzielono podrozdziały, które dotyczą: przestępstwa (zaniechania, winy, usiłowania, interpretacji poszczególnych przestępstw), kary (kary podzwyczajnej, chłosty, recydywy, zmiany kary izolacyjnej na pieniężną), procedury karnej. Brak przy tym odniesień do panującej wówczas szkoły klasycznej w prawie karnym, w tym współczesnych publikacji na ten temat ${ }^{11}$.

Rozdział kończący książkę, jak wyżej zaznaczono, został poświęcony publikacjom z zakresu prawa cywilnego. Omawiając artykuły, autor zastosował systematykę zaproponowaną przez Romualda Hubego, który wyróżnił cztery główne działy. Dodając jednak do tego podziału publikacje z zakresu procedury cywilnej oraz prawa handlowego, niesłusznie przy tym uznał, że dla tego okresu obowiązuje zasada jedności prawa cywilnego. Ostatnie zagadnienie o tyle jest istotne, iż w tym czasie prawo handlowe miało charakter odrębnej dyscypliny prawnej, a od średniowiecza określano je mianem ius mercatorum, czyli było to prawo stanu kupieckiego ${ }^{12}$. Konsekwencją tego było wykształcenie się w XIX wieku trzech systemów prawa handlowego: przedmiotowego, mieszanego oraz podmiotowego ${ }^{13}$.

W związku z tym autor wydzielił osobne podrozdziały, takie jak: prawo osobowe i rodzinne, prawo rzeczowe, zobowiązania, prawo spadkowe, prawo handlowe, postępowanie cywilne (kwestia obrońców duchownych, dowody, środki zaskarżenia, egzekucja, problematyka międzynarodowego postępowania cywilnego). Wywody autora ogólnie ograniczają się do omówienia poszczególnych artykułów zawartych w czasopiśmie w ramach wymienionych podrozdziałów oraz ich cytowania. Oprócz tego, bez większej refleksji naukowej, wymienił on (s. 215 książki) kwestię ,,podważenia” alienacji nieruchomości, jeśli sprzedano ją za mniej niż 5/12 wartości (art. 1674 Kodeksu

Polskim 1807-1867, Warszawa 1984; R. Jastrzębski, Trybunat Kompetencyjny. Kolegium Kompetencyjne. Geneza. Działalność. Wspótczesność, Warszawa 2014.

11 Zob. np. D. Janicka, Spór o teorie kary w dobie klasycznej szkoły prawa karnego na ziemiach polskich i niemieckich w XIX wieku, „Polska Akademia Umiejętności. Prace Komisji Historii Nauki” 2000, tom II.

12 Szerzej: J. Namitkiewicz, Próba charakterystyki i określenie prawa handlowego, PPH 1925, nr 2; J. Okolski, W. Opalski, Znaczenie prawa handlowego w świetle koncepcji jedności prawa cywilnego, PPH 1992, nr 1; S. Włodyka, O sposobach normatywnej regulacji prawa handlowego, „Państwo i Prawo” 1999, z. 9; J. Okolski, Koncepcja prawa handlowego w świetle zmian w prawie cywilnym, PPH 1997, nr 10; W. Uruszczak, Ius mercatorum - lex mercatoria. Prawo kupców - prawo kupieckie [w:] Ius mercatorum, lex mercatoria. $Z$ dziejów $i$ współczesności prawa handlowego, materiały konferencji poświęconej przeszłości i teraźniejszości prawa handlowego, Uniwersytet Jagielloński, Kraków 9-11 marca 2009 r., red. M. Mikuła, P. Suski, Kraków 2011; B. Fuchs, Lex Mercatoria w międzynarodowym obrocie handlowym, Kraków 2000; idem, Lex Mercatoria - od średniowiecza po XXI wiek [w:] O prawie i jego dziejach księgi dwie. Studia ofiarowane Profesorowi Adamowi Lityńskiemu w czterdziestopięciolecie pracy naukowej i siedemdziesięciolecie urodzin, księga II, Białystok-Katowice 2010.

13 Zob. R. Jastrzębski, Prawo handlowe in statu nascendi II RP - pojęcie i zagadnienia kodyfikacyjne, PPH 2015, nr 5. 
Napoleona $)^{14}$. Warto podkreślić, że ta instytucja wywodzi się z prawa rzymskiego - konstytucja cesarza Dioklecjana ${ }^{15}$. Ponadto podrozdział, który obejmuje prawo spadkowe, został oparty na wcześniejszym artykule z 2010 roku $^{16}$. W podsumowaniu rozdziału autor doszedł do ważnej dla siebie konkluzji, że publicystyka cywilistyczna była dla autorów „Themis Polskiej” ,,szczególnie interesująca” (s. 249 książki).

W zakończeniu książki, liczącym niecałe siedem stron, autor starał się między innymi nakreślić obraz kultury prawnej Królestwa Kongresowego w świetle „Themis Polskiej”, określić miejsce gazety na tle europejskim oraz zwrócić uwagę czytelnika na legendę i znaczenie czasopisma dla rozwoju polskiej kultury prawnej. W ostatniej kwestii doszedł do „wyjątkowych przemyśleń”, że czasopismo miało niewątpliwie wpływ na podniesienie stanu nauki prawa nad Wisłą i ,stało się dla młodych urzędników o ambicjach naukowych platformą wymiany myśli, której wcześniej i przez wiele lat później nie było" (s. 256 książki). Na koniec omawiania opisu zawartości książki należy zaznaczyć, że prawie połowę bibliografii stanowią artykuły opublikowane na łamach „Themis Polskiej”.

Jeśli chodzi o błędy redakcyjne, stylistyczne oraz językowe, można wśród nich wymienić:

1) używanie w niewłaściwym kontekście słów: zbić, zbijał, zbił (s. 141, 145, 192, 200 książki);

2) użycie sformułowań: „faza odziałała” (s. 113 książki); „,szczególnie ubodła sugestia” (s. 142 książki); „zostały zderogowane” (s. 149 książki); „skażonych decyzji” (chodziło raczej o ,zaskarżonych”, s. 171 książki); ,instytucją pozwalająca” (chodzi o „instytucją pozwalającą”, s. 189 książki); „cześć” (powinno być „,część”, s. 194 książki); „Argumentacja Hubego w tym zakresie zupełnie się nie broni” (s. 196 książki); , problemów wynikłych” (s. 236 książki); „objawiające się" (s. 249 książki); ,formować własne oczekiwania” (s. 252);

3) przekręcone nazwisko „Wincenty Niemojewski” powinno być „Niemojowski” (s. 220 książki);

4) w książce pojawia się „nowy” prawnik rzymski Paulian (s. 222), mimo że w treści czasopisma (tom 3, Warszawa 1828, s. 149) znajduje się explicite powołanie na Paulusa;

5) pisownia słowa „Z pośród” powinno być „Spośród” (s. 229 książki);

6) niezrozumiałe zmiany koloru czcionki (s. 27, 270, 278).

14 Art. 1674 Kodeksu Napoleona brzmi: „Jeżeli sprzedawca pokrzywdzony został więcej niż o siedem dwunastych ceny nieruchomości, służy mu prawo żądać zerwania sprzedaży, chociażby nawet w umowie zrzekł się był wyraźnie możności żądania takiego zerwania i chociażby oświadczył, że przewyżkę wartości darował”. Zob. Prawo cywilne obowiazujące w Królestwie Polskiem, Warszawa 1914, s. 379.

15 Zob. J.S.K., Pokrzywdzenie przy sprzedaży majątku ziemskiego, ,Gazeta Sądowa Warszawska” 1919, s. 23-25; R. Jastrzębski, Między nominalizmem a waloryzacja-judykatura in statu nascendi II Rzeczypospolitej, CPH 2011, t. 63, z. 1, s. 126.

16 Zob. P. Pomianowski, Ochrona własności na wypadek śmierci. Spór o ksztalt prawa spadkowego Królestwa Kongresowego, „Studia Iuridica” 2010, tom 52. 
3. Pora na podsumowanie. Omawiana książka stanowi kompilację poglądów jej autora, nierzadko luźno z sobą powiązanych, które dotyczą zawartości czasopisma „Themis Polska”, które ukazywało się przez trzy lata. Wynika z tego, że moje przewidywania z 2011 roku okazały się profetyczne. Erozja naukowa w zakresie opisywania zawartości czasopism poszła dalej.

Pytaniem podstawowym jest przydatność tego rodzaju „prac naukowych”, które ogólnie składają się z opisu zawartości czasopism, niejako „okraszonego” uwagami autora. Oczywiście, jeśli autorzy takich prac piszą tego rodzaju „monografie naukowe" na własny koszt, tym samym nie korzystając ze stypendiów, dofinansowań na ich wydanie, oraz nie są one pisane na stopnie naukowe, można je uznać nawet za pożyteczne. Potencjalnie bowiem mogą zwiększyć zdolności poznawcze szerokiego kręgu czytelników, o ile jednak interesują się oni określoną tematyką. W przeciwnym razie wypada uznać, mając na względzie interesy podatnika, że pieniądze na tego typu ,prace naukowe” zostały źle wydane ${ }^{17}$. Dodam przy tym, że recenzowana książka była związana $\mathrm{z}$ tak zwanym grantem promotorskim, a samo jej wydanie zostało dofinansowane ze środków publicznych. Warto przy tym zaznaczyć, że już w 1836 roku ukazała się, wydana w Warszawie broszura zatytułowana Spis rzeczy objętej w Themidzie Polskiej, która składa się ze wstępu oraz spisu treści tego czasopisma ${ }^{18}$, co - jak należy przypuszczać - ułatwiło autorowi dokonanie podziału poszczególnych zagadnień prawnych, opisywanych w recenzowanej książce.

Ponadto w 2011 roku przy udziale Naczelnej Rady Adwokackiej ukazała się, nienapisana zresztą na żaden stopień naukowy, o wiele poważniejsza „pozycja naukowa"19. Jej autorzy omówili czasopiśmiennictwo prawnicze na ziemiach polskich do 1939 roku. W ten sposób można dojść do wniosku, że do każdego z wymienionych w tej książce rozdziałów - dotyczących poszczególnych czasopism - można napisać odrębną pracę naukową, która składa się z omówienia zawartości czasopisma oraz przemyśleń, zapatrywań, refleksji jej autora na poszczególne zagadnienia prawne. W związku z tym można wyobrazić sobie prace o tytule na przykład: „Themis Polska II. Spichlerz czystej nauki”, „Początki polskiego prawniczego czasopiśmiennictwa handlowego na łamach Przeglądu Prawa Handlowego” czy „Przegląd Sądowy i Administracyjny. U źródeł polskiego czasopiśmiennictwa prawniczego w Galicji”.

Wypada jednak zadać istotne pytanie: jaka jest przydatność naukowa takich prac, które dodatkowo mogą zawierać statystkę zawartości czasopisma w postaci przeróżnych wykresów? Zresztą pisanie tego rodzaju prac naukowych nie wymaga dużego nakładu pracy, wystarczy bowiem poznać treść gazety oraz w zarysie epokę, w której czasopismo się ukazywało, i takie know-how powinno w zasadzie wystarczać

17 Zob. T. Giaro, Bezczeszczenie grobów w Rzymie a interes polskiego podatnika, „Forum Prawnicze” 2013 , nr 6.

18 Treść broszury: Wstęp, s. III-V; Spis rzeczy, s. VI-XVIII; podział zawartości czasopisma na: Prawo kryminalne (przedmioty ogólne, kodex kryminalny, procedura kryminalna), Prawo cywilne (przedmioty ogólne, kodex cywilny, kodex handlowy, procedura cywilna, postępowanie kassacyjne), Sądownictwo, Ustawa stemplowa, Roboty praktyczne, Nauka prawa i prawodawstwa, Prawodawstwo, Prawo polskie i inne współplemienne, Przedmioty obcych prawodawstw, Literatura.

19 Zob. S. Milewski, A. Redzik, Themis i Pheme. Czasopiśmiennictwo prawnicze w Polsce do 1939 roku, Warszawa 2011. 
do napisania ,pracy naukowej”. Ale żart na bok. Współcześnie przeżywamy epokę daleko posuniętego konformizmu, przeciętności i pójścia na łatwiznę w pracy naukowej. Zwrócił na to uwagę Jan Baszkiewicz, który uznał, że tylko krytyka „może powstrzymać erozję autorytetów i ekspansję technokratycznej iluzji”20. Ten problem zauważył również Bogusław Wolniewicz, który expressis verbis stwierdził w publikacji pod tytułem Krytyka naukowa i kryteria naukowości, że:

\footnotetext{
Negatywne recenzje w czasopismach, a także w przewodach doktorskich i habilitacyjnych, są rzadkością i przyjmuje się je raczej jako towarzyski nietakt niż jako oddawaną nauce polskiej przysługę. Ewentualni autorzy negatywnych recenzji, zamiast pisać, co myślą, wolą się od ich napisania pod jakimkolwiek pretekstem uchylić. Obawiają się bowiem, i często nie bez racji, że ostra krytyka zostanie zrozumiana jako wyraz osobistych uraz i animozji, wzbudzając niechęć do krytyka, a życzliwe współczucie dla skrytykowanego ${ }^{21}$.
}

Recenzowana książka wpisuje się właśnie we współczesne tendencje „naukowe”, których celem jest uzyskiwanie stopni naukowych niewielkim wysiłkiem, o czym świadczy treść pracy. Co istotne, książka ta, będąca w niewielkim stopniu zmienioną wersją pracy doktorskiej, daje autorowi potencjalną możliwość uzyskiwania kolejnych stopni naukowych. Oczywiście można ostatecznie uznać, że książka to książka, przy tym bez znaczenia jest jej treść merytoryczna, a że podatnik za to zapłacił - widocznie taka jego rola.

\section{Bibliografia}

Bałtruszajtys G., Sadownictwo Komisji Skarbowych w sprawach handlowych i przemysłowych (1764-1794), Warszawa 1977.

Dąbkowski P., Prawo prywatne polskie, t. I, Lwów 1910, t. II, Lwów 1911.

Filipowicz S., Uniwersytet Jana Baszkiewicza, CPH 2012, t. 64, z. 1.

Fuchs B., Lex Mercatoria - od średniowiecza po XXI wiek [w:] O prawie i jego dziejach księgi dwie. Studia ofiarowane Profesorowi Adamowi Lityńskiemu w czterdziestopięciolecie pracy naukowej i siedemdziesięciolecie urodzin, księga II, Białystok-Katowice 2010.

Fuchs B., Lex Mercatoria w międzynarodowym obrocie handlowym, Kraków 2000.

Giaro T., Bezczeszczenie grobów w Rzymie a interes polskiego podatnika, „Forum Prawnicze” 2013, nr 6.

Gołaszewski Ł., Spory o dziesięciny. Świeccy i duchowni w Knyszynie na przełomie XVI i XVII wieku, Warszawa 2016.

Grodziski S., Z dziejów staropolskiej kultury prawnej, Kraków 2004.

J.S.K., Pokrzywdzenie przy sprzedaży majątku ziemskiego, „Gazeta Sądowa Warszawska” 1919.

Janicka D., Spór o teorie kary $w$ dobie klasycznej szkoty prawa karnego na ziemiach polskich i niemieckich w XIX wieku, „Polska Akademia Umiejętności. Prace Komisji Historii Nauki” 2000, tom II.

Jastrzębski R., Między nominalizmem a waloryzacja - judykatura in statu nascendi II Rzeczypospolitej, CPH 2011, t. 63, z. 1.

20 S. Filipowicz, Uniwersytet Jana Baszkiewicza, CPH 2012, t. 64, z. 1, s. 199.

21 B. Wolniewicz, Filozofia i wartości II, Warszawa 1998, s. 268. 
Jastrzębski R., Prawo handlowe in statu nascendi II RP - pojęcie i zagadnienia kodyfikacyjne, PPH 2015, nr 5.

Jastrzębski R., Recenzja ksiązki Marzenny Paszkowskiej Nauka prawa karnego w środowisku „Gazety Sądowej Warszawskiej” (1873-1918), „Forum Prawnicze” 2011, nr 6.

Jastrzębski R., Trybunat Kompetencyjny. Kolegium Kompetencyjne. Geneza. Dziatalność. Wspótczesność, Warszawa 2014.

Kutrzeba S., Dawne polskie prawo sądowe w zarysie, Lwów 1926.

Milewski S., Redzik A., Themis i Pheme. Czasopiśmiennictwo prawnicze w Polsce do 1939 roku, Warszawa 2011.

Mogilnicki A., Sady administracyjne (Przedruk z ,,Gazety Sadowej”), Warszawa 1900.

Moniuszko A., Mazowieckie sądy ziemskie (1588-1648). Organizacja - funkcjonowanie - postępowanie, Warszawa 2013.

Moniuszko A., Prawo sądowe Rzeczypospolitej szlacheckiej (XVI-XVII w.). Zarys wykładu z wyborem źródet, Warszawa 2017.

Namitkiewicz J., Próba charakterystyki i określenie prawa handlowego, PPH 1925, nr 2.

Okolski A., O sporach administracyjnych. Rozprawa napisana w celu uzyskania stopnia Doktora Prawa i Administracji w Szkole Głównej Warszawskiej, Warszawa 1867.

Okolski J., Koncepcja prawa handlowego w świetle zmian w prawie cywilnym, PPH 1997, nr 10.

Okolski J., Opalski W., Znaczenie prawa handlowego w świetle koncepcji jedności prawa cywilnego, PPH 1992, nr 1.

Pałecki K., O użyteczności pojęcia kultura prawna, „Państwo i Prawo” 1974, z. 2.

Płaza S., Historia prawa w Polsce na tle porównawczym, cz. 1-3, Kraków 2002-2003.

Pomianowski P., Główne nurty ideologiczno-metodologiczne w środowisku warszawskich prawników przed wybuchem powstania listopadowego, ,Zeszyty Prawnicze UKSW” 2011, nr 4.

Pomianowski P., Ochrona własności na wypadek śmierci. Spór o ksztatt prawa spadkowego Królestwa Kongresowego, „Studia Iuridica” 2010, tom 52.

Pomianowski P., Seria pierwsza ,,Themis Polskiej” jako pismo poświęcone praktyce prawa, „Studia Iuridica" 2009, t. 50.

Pomianowski P.Z., Rozwód w XIX wieku na centralnych ziemiach polskich. Praktyka stosowania Kodeksu Napoleona w latach 1808-1852, Warszawa 2018.

Prawo cywilne obowiazujące w Królestwie Polskiem, Warszawa 1914, s. 379.

Sójka-Zielińska K., Historia prawa, Warszawa 1997.

Sójka-Zielińska K., Stanisława Russockiego dyskurs historyczny o kulturze prawnej [w:] Stanisław Russocki-badacz dziejów ustroju i prawa. W 45-lecie pracy naukowej, Warszawa 1999.

Sójka-Zielińska K., Wielkie kodyfikacje cywilne XIX wieku, Warszawa 1973.

Sójka-Zielińska K., Wielkie kodyfikacje cywilne. Historia i współczesność, Warszawa 2009.

Uruszczak W., Ius mercatorum - lex mercatoria. Prawo kupców - prawo kupieckie [w:] Ius mercatorum, lex mercatoria. $Z$ dziejów $i$ wspótczesności prawa handlowego, materiały konferencji poświęconej przeszłości i teraźniejszości prawa handlowego, Uniwersytet Jagielloński, Kraków 9-11 marca 2009 r., red. M. Mikuła, P. Suski, Kraków 2011.

Uruszczak W., Próba kodyfikacji prawa polskiego w pierwszej połowie XVI wieku. Korektura praw z 1532 r., Warszawa 1979.

Wąsowicz M., Rozstrzyganie sporów prawnych między podmiotami własności publicznej w Królestwie Polskim w latach 1817-1867, CPH 1981, t. 33, z. 1.

Witkowski W., Sadownictwo administracyjne w Księstwie Warszawskim i Królestwie Polskim 1807-1867, Warszawa 1984.

Włodyka S., O sposobach normatywnej regulacji prawa handlowego, „Państwo i Prawo” 1999, z. 9.

Wolniewicz B., Filozofia i wartości II, Warszawa 1998.

Zakrzewski A.B., Wielkie Księstwo Litewskie (XVI-XVIII w.). Prawo - ustrój-społeczeństwo, Warszawa 2013.

Artykuły recenzyjne - Reviews' articles 